\title{
Pemberitaan film A Man Called Ahok dan film 212 di media online
}

\author{
Safira Pratiwi Maulany ${ }^{1}$ dan Aceng Abdullah ${ }^{2}$ \\ ${ }^{1,2}$ Universitas Padjadjaran, Bandung, Indonesia
}

\begin{abstract}
ABSTRAK
Film A Man Called Ahok dan film 212: The Power of Love terinspirasi dari fenomena besar di masyarakat dan saling berhubungan di kehidupan nyata serta menarik perhatian media massa untuk memuat pemberitaannya, termasuk media online Republika dan CNN Indonesia yang diketahui memiliki perbedaan perspektif. Pemberitaan media dapat mempengaruhi eksistensi sebuah film, tetapi perbedaan perpektif media menyebabkan perbedaan sudut pandang dalam berita yang ditampilkan. Maka dari itu, penelitian ini bertujuan untuk melihat sejauh mana perbedaan dua media dalam membingkai pemberitaan mengenai film A Man Called Ahok dan film 212: The Power Of Love dengan menggunakan gunakan metode framing dari Robert N. Entman yang melihat framing dalam dua dimensi yakni seleksi isu dan penonjolan aspek tertentu, dan unsur analisis media yang terdiri dari pendefinisian masalah; memperkirakan penyebab masalah; nilai moral yang ditampilkan; dan penyelesaian masalah yang dimunculkan dalam pemberitaan oleh masingmasing media. Hasil penelitian menunjukan bahwa Republika mendefinisikan film 212: The Power of Love sebagai film Islam yang sangat bagus dan patut ditonton karena mencerminkan nilai kemanusiaan dan nilai Islam sesungguhnya yang cinta damai, dan dalam memberitakan film 212: The Power of Love Republika cenderung mengarah pada promosi. CNN Indonesia membingkai kegagalan film 212: The Power of Love untuk mencapai 1 juta penonton dan kedua media sama-sama mendefinisikan film A Man Called Ahok sebagai film biografi yang apik baik dari segi cerita maupun teknis film, mengaitkan film dengan isu politik juga dibingkai oleh CNN Indonesia sebagai cerminan polarisasi bangsa.
\end{abstract}

Kata-kata Kunci: Film; pemberitaan; aksi 212; Ahok; analisis framing

\section{News of A Man Called Ahok and 212 Films in online media}

\begin{abstract}
The A Man Called Ahok and 212: The Power of Love films are inspired by big phenomena in the community and are interconnected in real life and attracted the attention of mass media to publish their coverage, including media Republika online and CNN Indonesia which are known have different perspectives. Media reporting can influence the existence of a film, but differences in media perspective cause different points of view in the news displayed. Therefore, this research aims to see the extent of the differences in the two media in framing the coverage of the film A Man Called Ahok and the 212 film: The Power of Love by using framing method from Robert N. Entman who sees framing in two dimensions namely selection issue and highlighting certain aspects, and elements of media analysis which consist of define problems; diagnose causes; make a moral judgement; and treatment recommendation or resolution of problems raised in the media by each media. The results showed that Republika defines the 212 film: The Power of Love as an Islamic film that is very good and worth watching because it reflects the human values and the true value of Islam that loves peace, and in preaching the 212 film: The Power of Love Republika tends to lead to promotion. CNN Indonesia frames 212: The Power of Love film failure to reach 1 million viewers and the two media defines the film A Man Called Ahok as a slick biography both in terms of story and technical film, linking film with political issues is also framed by CNN Indonesia as a reflection of the nation's polarization.
\end{abstract}

Keywords: Film; news; 212 action; Ahok; framing analysis

Korespondensi: Safira Pratiwi Maulany, S.I.Kom. Universitas Padjadjaran. J1. Raya BandungSumedang Km. 21 Sumedang. Email: safira.pratiwivip@gmail.com 


\section{PENDAHULUAN}

Perbedaan perspektif media massa menyebabkan perbedaan dalam melihat sebuah permasalahan dan perbedaan pembingkaian beritanya. Setiap media memiliki alasan khusus dalam melakukan seleksi isu dan memilih aspek mana yang ingin ditonjolkan dalam pemberitaannya. Berita merupakan sumber informasi yang menjadi suatu kebutuhan bagi khalayak, tetapi sebuah berita yang harusnya bersifat objektif menjadi bahan pertimbangan karena semua berita yang dihasilkan oleh media merupakan hasil dari konstruksi media massa itu sendiri. Pemberitaan media massa yang berkaitan dengan sebuah film dapat mempengaruhi eksistensi film tersebut, bergantung pada citra yang dibangun oleh sebuah media terhadap suatu film.

Saat ini banyak film yang sengaja mengangkat sebuah fenomena besar dimasyarakat, karena dalam industri film terdapat bisnis yang menguntungkan, dan seringkali karena mengutamakan uang sebuah film menjadi keluar dari kaidah artistik film itu sendiri. Pada tahun 2016-2017 Indonesia diramaikan oleh kasus penistaan agama Islam yang dilakukan oleh Ahok alias Basuki Tjahaja Purnama yang saat itu menjabat sebagai gubernur DKI Jakarta saat sedang berpidato di Kepulauan Seribu ia menyinggung surat AlMaidah ayat 51. Kasus penistaan agama Islam membuat masyarakat Indonesia yang mayoritas Muslim merasa geram dan menuntut Ahok untuk dihukum penjara. Tuntutan masyarakat tersebut disampaikan melalui aksi bela Islam yang digelar di Jakarta dan pesertanya berasal dari berbagai kalangan, yang dilaksanakan pada 2 Desember 2016 atau umumnya disebut aksi 212. Aksi tersebut dihadiri ribuan umat Muslim dari berbagai daerah yang berkumpul di pusat kota Jakarta dan berjalan kaki dari Bundaran HI sampai Monumen Nasional.

Fenomena tersebut menginspirasi sutradara Jastis Arimba untuk membuat film 212: The Power of Love yang rilis pada 9 Mei 2018. Film ini mengisahkan tentang Rahmat seorang jurnalis yang memiliki pandangan berbeda dengan ayahnya yang begitu taat agama dan berusaha mencegah ayahnya untuk ikut aksi 212 karena dianggap dapat memicu kerusuhan. Sosok Ahok yang begitu menarik perhatian menginspirasi Rudy Valinka untuk membuat novel berjudul A Man Called \#Ahok yang berhasil meraih predikat best seller akhirnya dijadikan sebuah film biografi berjudul $A$ Man Called Ahok yang disutradarai oleh Putrama Tuta yang dirilis pada 8 November 2018 dengan mengambil sudut cerita tentang hidup Ahok dan keluarganya saat tinggal di Belitung sejak Ahok kecil sampai masuk dunia politik.

Kedua film ini sama-sama diangkat dari fenomena yang viral pada tahun 2016-2017 saling berhubungan dalam dunia nyata dan menarik perhatian publik. Kedua film ini juga sama-sama memiliki target penonton yang tinggi, karena berekspektasi pada begitu viralnya sosok Ahok dan juga banyaknya pengikut aksi damai bela Islam 212 yang akan tertarik untuk menonton film ini. Tetapi film 212: The Power of Love yang tayang lebih dulu ternyata mendapat jumlah penonton kurang dari 500.000 dan mendapat rating 6/10 di situs filmindonesia. or.id, sedangkan film Ahok bisa dikatakan lebih sukses menarik jumlah penonton. Data Jumlah Penonton dapat dilihat pada Tabel 1.

Film A Man Called Ahok menempati peringkat ke-10 dalam daftar 15 film Indonesia teratas berdasarkan tahun edar 2018 dan mendapat rating 7,5/10 dari situs yang sama. Kedua film ini tidak mengandung unsur politik dan tidak saling menyinggung dari segi cerita tetapi kedua film ini diangkat dari kisah atau fenomena besar yang saling berhubungan di dunia nyata dan menarik perhatian publik dan media. Berbagai tanggapan mewarnai pemberitaan di media selama masa promosi

Tabel 1 Perolehan jumlah penonton

\begin{tabular}{cc}
\hline Judul Film & Jumlah Penonton \\
\hline A Man Called Ahok & 1.465 .145 \\
$\begin{array}{c}\text { 212: The Power of } \\
\text { Love }\end{array}$ & 363.636 \\
\hline
\end{tabular}

Sumber: Hasil penelitian, 2019 
film ini. Effendi mengatakan:

Tujuan khalayak menonton film sama seperti menonton televisi yakni ingin memperoleh hiburan. Film mengandung fungsi sebagai media edukatif, informatif, dan bahkan media persuasif, film nasional juga dapat digunakan sebagai media edukasi untuk pembinaan generasi muda, sesuai dengan misi perfilman nasional tahun 1979 dan fungsi edukasi tersebut akan tercapai apabila film nasional dapat objektif dalam memproduksi film sejarah, dan secara berimbang membuat film dokumenter (Ardianto, dkk., 2007).

Film dalam komunikasi massa berfungsi sebagai media pendidikan, hiburan, informasi, dan pendorong tumbuhnya industri kreatif lain. Film lebih dulu menjadi media hiburan dibanding radio dan televisi, menonton film di bioskop sudah menjadi aktivitas populer di Amerika sejak tahun 1950-an (Ardianto, Komala \& Karlinah, 2009). Walaupun film dianggap sebagai media hiburan tetapi film juga dijadikan sebagai media pembujuk karena film memiliki kekuatan persuasi yang besar. Adanya lembaga sensor film menandakan bahwa film sangat berpengaruh pada khalayak.

McQuail menyatakan bahwa keinginan untuk merefleksikan kondisi masyarakat terkandung dalam pesan sebuah film bahkan mungkin juga keinginan untuk memanipulasi. Pemanfaatan film dalam bidang pendidikan sangat penting mengingat bahwa kekuatan film untuk menarik perhatian orang begitu besar dan film merupakan media pengantar pesan yang unik (McQuail, 2010).

Semakin tinggi jumlah peminat film membuat persaingan baik di dalam maupun di luar industri film semakin ketat, semakin banyak jumlah film yang beredar semakin bervariasi pula pilihan bagi khalayak, di era modern ini ulasan atau pemberitaan di media online kerap kali menjadi acuan maupun bahan pertimbangan bagi khalayak untuk menonton sebuah film, karena informasi dari media online mudah diakses, beragam dan up to date.

Munculnya teknologi komputasi yang mengubah lanskap media massa dalam berbagai cara, dari mulai konten media yang dibuat dalam bentuk digital, berubahnya teknik produksi media, distribusi media secara global, terciptanya interaktivitas yang lebih besar antara pengguna media, serta bentuk dan fitur perangkat komputasi yang semakin bervariasi. (Permana, 2019). Media elektronik juga dapat menciptakan ledakan informasi, serta menjadi persaingan antar media memperebutkan perhatian audien. Informasi dari media memiliki harga dan nilai jual sehingga dijadikan ladang bisnis yang menciptakan tekanan bagi pemberi informasi. Di Indonesia media online yang cukup terkenal diantaranya ada Detik.com, Liputan6.com, Tribun News, CNN Indonesia, Kumparan, dan lain-lain, media cetak pun turut beralih ke media online seperti Tempo, Republika, Kompas, dan Sindo.

Peneliti memilih media Republika online karena Republika adalah koran nasional yang telah berdiri sejak tahun 1992 dan masih eksis hingga saat ini, serta memiliki segmentasi khalayak tersendiri tetapi masih diterima secara umum, Republika juga merupakan koran umat Muslim karena dibidani oleh ICMI (Ikatan Cendekiawan Muslim Indonesia) yang sampai sekarang dikenal sebagai koran bernafaskan Islam. Peneliti juga memilih media CNN Indonesia atau Cable News Network Indonesia karena media yang masih bekerjasama dengan CNN Internasional ini berhasil menarik perhatian masyarakat sejak perilisannya pada tahun 2015, terbukti dengan masuknya nama CNN Indonesia dalam 10 besar situs berita online terpopuler di Indonesia berdasarkan data dari www.alexa.com dan CNN Indonesia juga memiliki segmentasi khalayak yang lebih umum. Perbedaan latar belakang media ini dapat memengaruhi pandangan kedua media tersebut terhadap suatu isu, maka dari itu peneliti ingin melihat sejauh mana perbedaan sudut pandang Republika online dan CNN Indonesia dalam membingkai berita. Perbedaan ideologi kedua media juga menjadi penentu cara masingmasing media dalam mengkonstruksi realitas.

Kasus penistaan agama Islam yang dilakukan oleh Ahok serta peristiwa aksi damai 212 menarik banyak perhatian peneliti dari berbagai bidang terutama yang berfokus pada 
konstruksi atau pembingkaian media terkait peristiwa tersebut, mengingat kontennya cukup sensitif untuk diberitakan. Seperti penelitian yang dilakukan oleh Lidya Agustina seorang peneliti dari Puslitbang Aptika IKP Kementerian Komunikasi dan Informatika yang ingin melihat bagaimana media online membingkai peristiwa aksi 212 dan dari hasil penelitiannya ditemukan bahwa Republika. co.id ternyata lebih aktif dalam memberitakan peristiwa aksi bela Islam 212 yang dianggap bahwa aksi 212 ini penting untuk diberitakan oleh Republika.co.id serta penonjolan aspekaspek Islami dalam pemberitaannya tentang aksi 212, meskipun peristiwa yang disampaikan memiliki kesamaan tetapi Kompas.com lebih tenang dalam penyampaian beritanya dan juga lebih bersifat netral.

Penelitian lain yang juga berkaitan yakni penelitian oleh Ahmad Rofiul Ilmi Alauddin yang berjudul "Konstruksi Pemberitaan Kasus Ahok di Media Online Tentang Penistaan Agama" dimana hasil penelitiannya memperlihatkan Republika.co.id berpandangan bahwa nilai islam bisa bersinergi dengan peraturan pemerintah dan pidato Ahok tentang surat Al Maidah ayat 51 merupakan bentuk pelanggaran, sedangkan Kompas.com memiliki pandangan pemberitaan yang tendensius akan nilai toleransi dan menginginkan adanya pemisahan antara politik dan agama sehingga kasus ini tidak ada bentuk pelecehan agama.

Penelitian sebelumnya memperkuat pernyataan bahwa media tidak lagi hanya sebagai penyampaian pesan tetapi media dapat juga memengaruhi opini dan sikap masyarakat. Hal tersebut pada akhirnya memunculkan bias media, media yang harusnya mewakili kepentingan masyarakat, justru jadi memiliki kepentingan ekonomi dan politik masingmasing (Nugroho, 2018). Pemberitaan film dapat memengaruhi eksistensi sebuah film karena pemberitaan akan memengaruhi opini penonton, khalayak yang membaca berita atau artikel di suatu media sebelum menonton film dapat terpengaruh opini dan keputusannya untuk menonton film tersebut atau tidak, dan yang membaca berita atau artikel di media sesudah menonton film pun dapat tergiring pandangannya pada film tersebut sebagaimana film itu dikonstruksikan atau dibingkai oleh media. Karena media tidak sekedar mengamati kejadian kemudian memberitakannya, tetapi media memposisikan sebuah peristiwa dalam konteks tertentu, memilih frame dan sumbersumber tertentu, serta mengemukakan analisis dan interpretasi tertentu (Pawito, 2009). Maka dari itu, peneliti tertarik untuk melihat bagaimana media Republika online dan CNN Indonesia membingkai pemberitaan mengenai film $A$ Man Called Ahok dan film 212: The Power of Love yang banyak menuai kontroversi, karena diketahui isi sebuah pemberitaan dapat mengkonstruksi opini publik dan mempengaruhi eksistensi sebuah film, serta peneliti juga ingin melihat apa yang membuat film 212 The Power of Love gagal mencapai target penontonnya, bagaimana hal tersebut didefinisikan oleh media dan apakah ada pengaruh dari pemberitaan media atau memang faktor dari kualitas film itu sendiri atau adanya faktor lain.

\section{METODE PENELITIAN}

Penelitian ini menggunakan metode kualitatif untuk menganalisis teks berita, dan pembahasan hasil analisis yang bersifat deskriptif. Penelitian Kualitatif merupakan penelitian yang menggunakan penafsiran dan melibatkan banyak metode dalam menelaah masalah penelitiannya, penggunaan banyak metode ini bertujuan agar peneliti mendapatkan pemahaman yang komprehensif mengenai suatu fenomena yang diteliti (Mulyana, 2008). Dengan menggunakan pendekatan deskriptif kualitatif peneliti juga dapat mengungkapkan sejumlah argumentasi media dalam menyuguhkan pilihan informasi kepada masyarakat yang bertujuan agar publik semakin mudah menangkap pesan dan mengikuti arus wacana yang disampaikan media (Wazis, 2012). Dalam menganalisis teks berita peneliti menggunakan analisis framing yang termasuk dalam paradigma konstruktivisme yang memiliki pandangan bahwa media massa mengkonstruksi informasi dan menyebarkannya kepada khalayak, media tidak mungkin melakukan peranan yang netral, 
media pasti terpengaruh sumber dari internal organisasi media tersebut maupun dari luar media, sama hal nya dengan khalayak yang mengkonstruksikan informasi yang diterima berdasarkan skematanya masing-masing (Wazis, 2012). Peneliti menggunakan model analisis framing Robert N. Entman yang membagi framing dalam dua dimensi, yakni seleksi isu dan penonjolan aspek-aspek tertentu dari realitas atau suatu isu (Eriyanto, 2002).

Dalam penonjolan aspek tertentu berkaitan dengan bagaimana media menulis fakta. Bagaimana aspek tertentu dalam sebuah peristiwa diseleksi hingga ditulis, sangat berkaitan dengan kata, kalimat, gambar, dan citra tertentu yang digunakan dan ditampilkan kepada khalayak, seperti pengulangan kata atau kalimat, kiasan tertentu untuk menggambarkan sesuatu, pemakaian grafis, asosiasi terhadap simbol budaya, generalisasi, simplifikasi, dan sebagainya (Kriyanto, 2007).

Dari pemikiran di atas, Entman merumuskannya ke dalam bentuk model framing (Kriyanto, 2007). Penulis menyajikan perangkat dan deskripsi model framing Entman tersebut di dalam Tabel 2.

Teknik pengumpulan data yang digunakan oleh peneliti terdiri dari dokumentasi teks berita dan potongan gambar dari media online Republika dan $\mathrm{CNN}$ Indonesia terkait pemberitaan film A Man Called Ahok dan film 212: The Power of Love merupakan bagian penting dan utama dalam pengumpulan data yang sesuai dengan kebutuhan penelitian ini. Peneliti juga melakukan studi kepustakaan, analisis berita, dan wawancara pra-riset kepada beberapa masyarakat umum terkait pengetahuan masyarakat tentang film 212 The Power of Love dan film A Man Called Ahok, dari analisis dan wawancara pra-riset tersebut peneliti melihat bahwa review atau pemberitaan media dapat berpengaruh pada keputusan masyarakat untuk menonton film.

Subjek dalam penelitian ini adalah media Republika online dan CNN Indonesia. Objek dalam penelitian ini adalah artikel atau teks berita yang terkait dengan pemberitaan film A Man Called Ahok dan film 212: The power of love yang dirilis atau diberitakan pada tahun 2018-2019. Terdapat sekitar 30 berita dari website Republika online dan 18 berita dari CNN Indonesia yang membahas tentang film A Man Called Ahok dan film 212: The Power of love tetapi peneliti hanya memilih 10 berita sebagai sampel yang peneliti anggap isi berita tersebut berfokus pada penilaian dan pembingkaian opini masing-masing media pada kedua film tersebut, serta dari segi isi berita yang lebih lengkap dari berita lainnya. Daftar judul berita yang dijadikan sampel penelitian penulis sajikan di dalam Tabel 3.

Tabel 2 Skema analisis framing Entman

\begin{tabular}{|c|c|c|}
\hline No & Perangkat & Deskripsi \\
\hline 1. & Pendefinisian masalah (define problems) & Bagaimana suatu peristiwa atau isu dilihat? \\
\hline 2. & $\begin{array}{l}\text { Memperkirakan masalah atau sumber } \\
\text { masalah (diagnose causes) }\end{array}$ & $\begin{array}{l}\text { Apa yang dianggap sebagai penyebab suatu } \\
\text { masalah? }\end{array}$ \\
\hline 3. & $\begin{array}{l}\text { Membuat pertimbangan moral (make } \\
\text { moral judgement) }\end{array}$ & $\begin{array}{l}\text { Nilai moral apa yang disajikan untuk } \\
\text { menjelaskan masalah, untuk melegitimasi dan } \\
\text { mendelegitimasi suatu tindakan? }\end{array}$ \\
\hline 4. & $\begin{array}{l}\text { Penyelesaian masalah (treatment } \\
\text { recommendation) }\end{array}$ & $\begin{array}{l}\text { Bagaimana cara mengatasi masalah atau isu? } \\
\text { Jalan apa yang ditawarkan untuk mengatasi } \\
\text { masalah? }\end{array}$ \\
\hline
\end{tabular}

Sumber: Hasil penelitian, 2019 
Tabel 3 Sampel penelitian

\begin{tabular}{|c|c|c|}
\hline No. & Judul Berita & Terbit \\
\hline 1. & [Republika] Film 212: The Power of Love Diapresiasi & 11 Mei 2018 \\
\hline 2. & [Republika] Erick Yusuf Terima Keluhan Sulitnya Tiket Film 212 & 11 Mei 2018 \\
\hline 3. & [Republika] Film 212 jadi Penyejuk di tengah Teror Bom Surabaya & 16 Mei 2018 \\
\hline 4. & [Republika] Film Ahok tak Angkat Kehidupan Politiknya & 7 September 2018 \\
\hline 5. & [Republika] Film A Man Called Ahok akan Dibuat Versi Panjang & 24 Januari 2019 \\
\hline 6. & $\begin{array}{l}\text { [CNN Indonesia] Mengukur Kemampuan Film '212’ Memutihkan } \\
\text { Bioskop }\end{array}$ & 11 Mei 2018 \\
\hline 7. & [CNN Indonesia] Ulasan Film: 212 The Power of Love & 10 Mei 2018 \\
\hline 8. & [CNN Indonesia] Ulasan Film: A Man Called Ahok & 8 November 2018 \\
\hline 9. & $\begin{array}{l}\text { [CNN Indonesia] A Man Called Ahok, Sepenggal Kisah Tentang } \\
\text { Basuki }\end{array}$ & 5 September 2018 \\
\hline 10. & [CNN Indonesia] Polarisasi Bangsa di Balik film Ahok dan Hanum & 14 November 2018 \\
\hline
\end{tabular}

Sumber: Hasil penelitian, 2019

\section{HASIL DAN PEMBAHASAN}

Bagian satu: Pendefinisian Masalah (Define Problems). Republika mendefinisikan film 212: The Power of Love sebagai film yang membangkitkan ghirah Islam serta mencerminkan nilai-nilai Islam sesungguhnya yang damai dan penuh cinta. film 212: The Power of Love juga dianggap sebagai memori dari aksi damai 212 dan karena beberapa alumni aksi damai 212 juga terlibat dalam pembuatan film ini maka film 212: The Power of Love bertekad untuk 'memutihkan bioskop', Oki Setiana Dewi selaku eksekutif produser juga memiliki target untuk mencapai 1 juta penonton. Republika menonjolkan dukungan dan apresiasi dari berbagai pihak baik dari lingkungan selebriti, ulama, hingga politikus yang menilai film 212: The Power of Love sebagai film yang sangat bagus dan bermanfaat karena mengandung pesan moral yang positif, film ini dinilai sangat universal tidak hanya untuk umat Muslim tapi untuk seluruh anak bangsa, seperti kutipan berikut: "Menurut Prabowo, film 212 The Power of Love sangat humanis. Bisa ditonton semua kalangan. Kalau skala nilainya 1 sampai 10, maka film ini nilainya adalah 9,9," Kata Helvy Tiana Rosa (Judul berita: film 212 The Power of Love Diapresiasi, paragraf 5).

Berbeda dengan Republika, CNN Indonesia mendefinisikan kegagalan film 212: The Power of Love dalam mencapai ambisinya untuk 'memutihkan bioskop' serta mandapat 1 juta penonton. CNN Indonesia membingkai bahwa euforia masa promosi film 212: The Power of Love dianggap berlebihan tidak sesuai dengan kualitas filmnya. CNN Indonesia mengkritik film 212: The Power of Love tidak berhasil menyampaikan pesannya, judul 'The Power of Love' dianggap dipaksakan masuk ke dalam film melalui satu karakter, bahkan film 212: The Power of Love dikatakan seperti sinetron walaupun film ini tetap dinilai baik soal agama dan keluarga.

Sutradara Jastis Arimba seakan hanya berputar pada konflik keluarga antara Rahmat dan ayahnya yang tak kunjung usai. Aksi 212 hanya dijadikan penguat konflik antara Rahmat dan ayahnya (Judul berita: film 212 The Power of Love Diapresiasi, paragraf 7). konflik yang berkepanjangan dan mudah ditebak membuat film 212 seperti sinetron. Meskipun, film itu tentu sarat nilai baik soal agama, cinta dan keluarga (Judul berita: film 212 The Power of Love Diapresiasi, paragraf 9).

Film A Man Called Ahok didefinisikan oleh Republika hanya sebagai sebuah karya film biografi dari sosok Ahok yang tidak mengandung nilai politik walaupun Ahok terkenal sebagai 


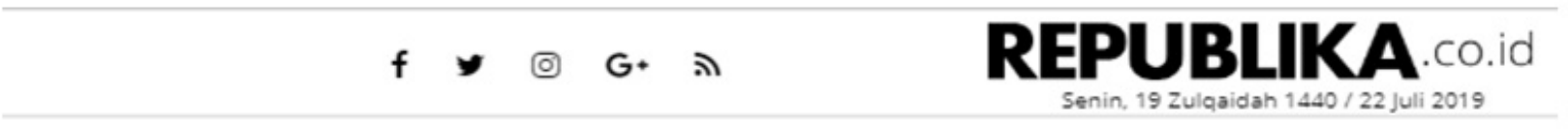

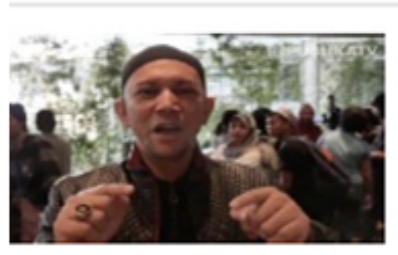

Film 212 The Power of Love dan Kebangkitan Islam

Wednesday, 02 May 2018 12:02 WIB

REPUBLIKA.CO.ID, JAKARTA - Eksekutif produser film 212 The Power of Love, Erick Yusuf, mengaku ada pesan besar di dalam film religi tersebut. Erick mengatakan, pesan yang ingin disampaikan adalah memperlihatkan...

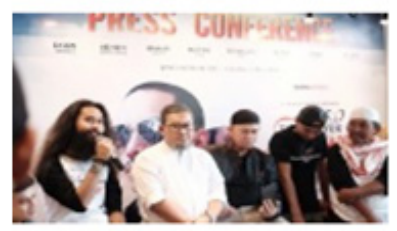

Pemutaran Perdana Film 212, Penonton Padati Bioskop

Wednesday, 09 May $201819: 24$ WIB

REPUBLIKA.CO.ID, JAKARTA - Lebih dari 50 ribu orang menonton film 212 The Power of Love pada pemutaran perdananya, Rabu (9/5). Bahkan, menurut Produser Eksekutif Film 212 The Power of Love,...

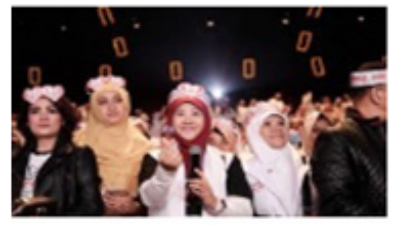

\section{Film 212 The Power of Love Diapresiasi}

Friday, 11 May 2018 01:22 WIB

REPUBLIKA.CO.ID, JAKARTA - Film 212 The Power of Love, yang tayang di bioskop nasional sejak 9 Mei 2018, diapresiasi oleh banyak tokoh. Mereka memuji film produksi Warna Pictures itu...

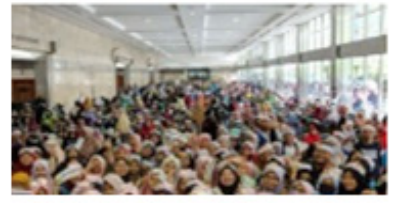

\section{Asma Nadia: Ini 3 Manfaat Nonton Film 212 The Power of} Love

Monday, 30 Apr 2018 09:32 WIB

Sumber: Republika, 2018

\section{Gambar 1 Pemberitaan 212 di Republika}

sosok politikus tetapi film A Man Called Ahok hanya mengangkat kisah hidup Ahok saat di Belitung. Di sisi lain film A Man Called Ahok didefinisikan sebagai film biografi yang apik oleh CNN Indonesia, CNN Indonesia menilai film ini berhasil memanfaatkan hubungan antara orangtua dan anak dalam mendidik dan menunjukan arti kasih sayang. film $A$ Man Called Ahok tak hanya dinilai bagus dari segi cerita oleh CNN Indonesia tetapi juga dari segi sinematografi, penggambaran budaya Tionghoa yang tidak berlebihan, serta para pemeran yang berhasil membawakan karakternya masingmasing dengan stabil.

Film A Man Called Ahok rilis bersamaan dengan film Hanum \& Rangga dan sempat menjadi perdebatan publik di media sosial karena diketahui latar belakang kedua film tersebut berasal dari dua kubu politik yang bersebrangan, film Hanum \& Rangga mengangkat cerita hidup
Hanum Rais yang merupakan anak dari Amien Rais dan notabenenya adalah lawan politik dari Ahok. CNN Indonesia membingkai bahwa masalah perdebatan politik yang melingkupi film A Man Called Ahok dan film Hanum \& Rangga merupakan cerminan polarisasi politik yang sudah lama terjadi di Indonesia.

Bagian dua: Memperkirakan Penyebab Masalah (Diagnose Causes). Republika dan CNN Indonesia dalam pemberitaannya tentang film 212: The Power of Love sama-sama membahas adanya masalah keterbatasan layar yang diberikan pihak pengelola bioskop untuk film 212, CNN Indonesia menilai faktor yang menyebabkan sedikitnya jumlah layar yang diberikan untuk film 212: The Power of Love karena kebijakan pihak bioskop terkait bisnis yang tidak ingin melepas layarnya dari film blockbuster Avengers: Infinity War.

Berdasarkan penghitungan CNNIndonesia. 


\section{Polarisasi Bangsa di Balik Film Ahok dan Hanum}

CNN Indonesia

Rabu, 14/11/2018 07:48
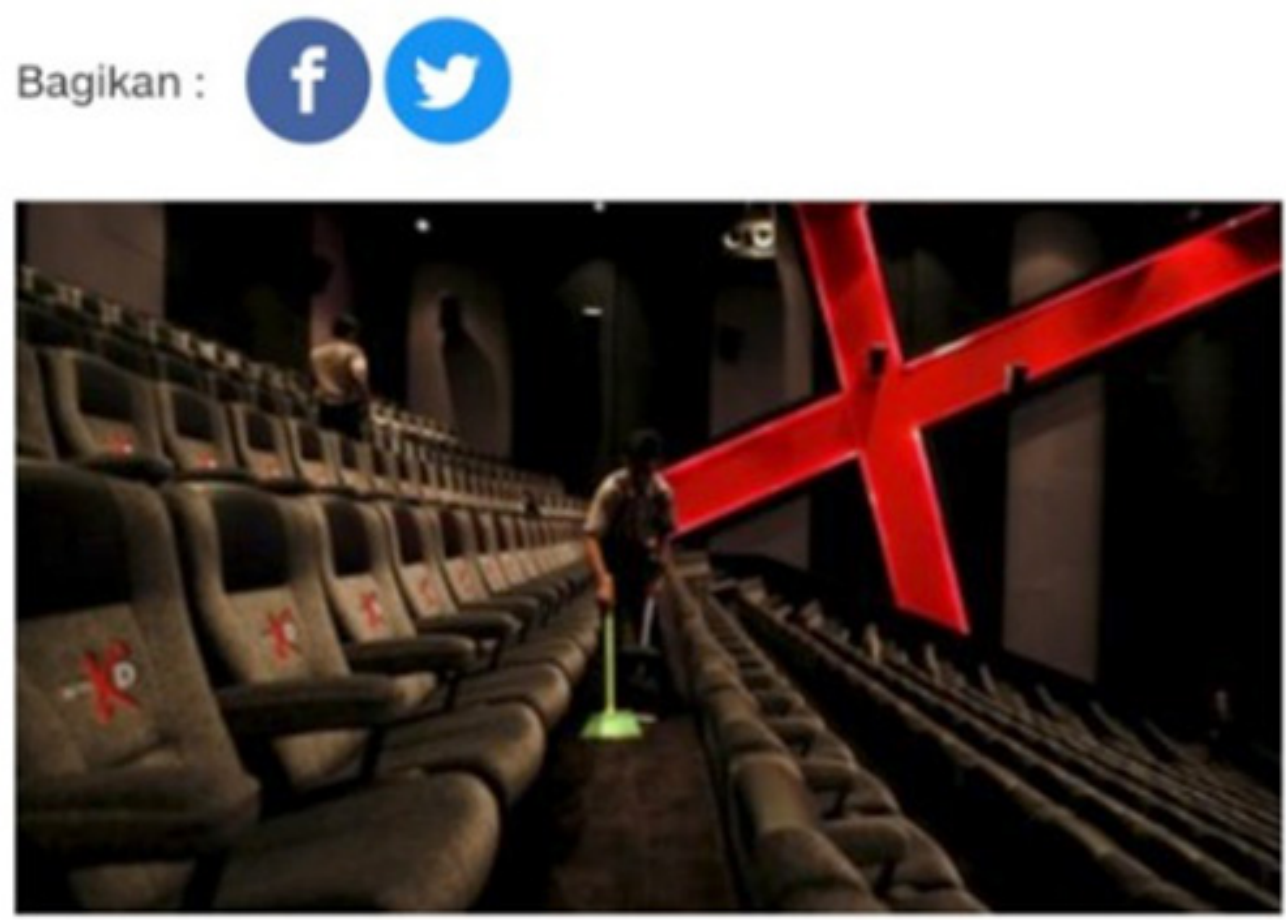

A Man Called Ahok serta Hanum\&Rangga, dua film beda genre dan segmen yang diputar di bioskop secara bersamaan telah mengundang kegaduhan politik.. (REUTERS/Darren Whiteside)

Sumber: CNN Indonesia, 2018

Gambar 2 Berita Polarisasi bangsa

com pada tiga jaringan bioskop terbesar di Indonesia, yaitu Cinema XXI, Cinemaxx, dan CGV, 212 The Power of Love di hari pertama tayang hanya diberikan 135 layar di sekitar 40 kota di Indonesia. Memantau dari laman resmi Cinema XXI, jaringan bioskop terbesar dengan kepemilikan 970 dari 1.578 layar lebar di Indonesia itu hanya memberikan 80 layar pada film 212 di 25 kota. Jakarta jadi kota dengan layar terbanyak, yaitu tiga layar di tiga lokasi. Jaringan Cinemaxx diketahui memberikan 22 layar untuk film 212. Sedangkan CGV Blitz memberikan layar terbanyak untuk 212, yaitu 83 layar di 31 lokasi bioskop mereka. Dengan jatah rata-rata layar film 212 adalah satu layar dengan jam penayangan dua hingga lima kali per layar per hari, maka pihak produser harus bekerja keras untuk bisa 'memutihkan' bioskop (Judul berita: Mengukur Kemampuan film 212 Memutihkan Bioskop, paragraf 7-10).

Walaupun akhirnya ada penambahan jumlah layar di hari ketiga penayangan tetap saja jumlahnya masih dianggap kurang. Faktor lainnya yang dipaparkan oleh CNN Indonesia adalah dari segi cerita dan sinematografi dikatakan tidak terlalu bagus karena banyak hal yang terkesan dipaksakan dalam film ini. CNN Indonesia juga menunjukan banyaknya 
kekurangan dari segi teknis dalam film 212: The Power of Love.

Ada beberapa adegan percakapan yang jelas terlihat di-dubbing, sutradara kurang memperhatikan logika waktu, penggunaan green screen yang terasa dibeberapa adegan, pengambilan shot yang memperlihatkan sedikit orang padahal massa aksi 212 jumlahnya sangat banyak. Teknik kamera yang kurang mulus, serta naskah yang kurang matang membuat film 212 garapan rumah produksi Warna Pictures itu cukup mendapat angka 6 dari 10 (Judul berita: Ulasan Film 212 The Power of Love, paragraf 10-13).

Masalah yang dibingkai Republika dan CNN Indonesia tentang film A Man Called Ahok adalah karena latar belakang Ahok yang merupakan seorang politikus maka banyak yang menilai bahwa film A Man Called Ahok akan menyinggung kehidupan politiknya tetapi kedua media menegaskan bahwa dalam film ini tidak berfokus pada kehidupan politik Ahok, dan orang-orang diluar Indonesia banyak yang tertarik dengan sosok Ahok dikarenakan dunia internasional yang memperhatikan iklim politik Indonesia.

Bagian tiga: Membuat Keputusan Moral (Make Moral Judgement). Nilai moral yang ditunjukan oleh CNN Indonesia dan Republika adalah makna dari film 212: The Power of Love yang menunjukan nilai-nilai agama dan kemanusiaan yang universal, humanis, baik untuk semua kalangan, serta semangat dalam mendukung film-film Islam yang bermutu dan bermanfaat, Republika juga mengajak penikmat film untuk bersifat objektif dan tidak lebih dulu berasumsi sebelum menyimak sebuah film. "Tonton dan nikmati dulu filmnya, setelah itu silahkan menilai. Jangan berburuk sangka dulu," "Pesan moral yang ingin disampaikan agar masyarakat lebih objektif melihat persoalan yang ada," kata Jastis Arimba (Judul berita: film 212 jadi penyejuk di tengah teror bom Surabaya, paragraf 8-10).

Nilai moral dari pemberitaan film $A$ Man Called Ahok terdapat pada penggambaran makna film tersebut yang menunjukan nilai sebuah keluarga, serta dapat menjadi cerminan bagi para orangtua dan anak. Dan di sisi lain film A Man Called Ahok dan film Hanum \& Rangga hanya memperkuat psikologi publik yang berpolarisasi. Republika membingkai pesan moral film A Man Called Ahok dibuat untuk tujuan yang positif dan diharapkan menjadi film yang inspiratif.

Bagian empat: Penyelesaian Masalah (Treatment Recommendation). Republika tidak menawarkan solusi dalam pemberitaannya terkait masalah film A Man Called Ahok maupun film 212: The Power of Love, Republika lebih banyak mengajak masyarakat untuk menonton film 212: The Power of Love yang dianggap dapat memberikan pencerahan dan penyejuk dalam permasalahan terorisme dan masalah lain yang menyangkut agama Islam, karena film ini dianggap menampilkan nilai-nilai Islam yang positif. Sedangkan CNN Indonesia menawarkan beberapa solusi untuk masalah film 212 seperti dengan menambah jumlah kopi-an film agar bisa ditayangkan dibeberapa layar sekaligus dalam satu bioskop, kemudian pemasaran melalui media sosial dan pengerahan massa alumni 212 untuk meningkatkan performa penjualan tiket film 212: The Power of Love.

$\mathrm{CNN}$ Indonesia menampilkan beberapa solusi untuk masalah politik yang melingkupi film A Man Called Ahok dengan mengutip saran Ubedilah Badrun yang berpendapat jika kondisi seperti yang terjadi pada film $A$ Man Called Ahok dan film hanum \& Rangga dapat diredam dengan cara melakukan edukasi politik gagasan kepada masyarakat, "Edukasi politik di mana dalamnya disampaikan gagasan politik, ide-ide pentingnya," (Judul berita: Polarisasi Bangsa di Balik film Ahok dan Hanum, paragraf 31). Masing-masing kubu politik sebaiknya membentuk tim untuk memberikan edukasi politik gagasan kepada masing-masing pendukungnya agar kondisi seperti itu tidak terjadi lagi.

Bagian lima: Seleksi Isu dan Penonjolan Aspek Tertentu Dari Isu. McQuail menyatakan bahwa media massa tidak boleh fokus pada satu isu tertentu saja dalam pemberitaannya (Morissan, 2010). Prinsip Diversity atau keragaman berita merupakan usaha media dalam memberikan berita yang lengkap dan 
adil, hal ini didasari oleh prinsip keterwakilan secara proporsional. Pemberitaan yang dibuat harus berlandaskan topik-topik yang sesuai untuk masyarakat dan menggambarkan berbagai kebutuhan audien terhadap berita. Pada pemberitaan kerap adanya bias yang mengacu pada hal-hal seperti penyimpangan terhadap realitas, penggambaran kelompok-kelompok minoritas dalam bentuk negatif, menguragi atau mengabaikan peran wanita dalam masyarakat, serta mendukung sebuah filosofi atau suatu pihak politik. Berita yang mengandung bias akan menjadi berita bohong atau dianggap sebagai propaganda seperti sebuah kisah fiksi.

Konsep penting dalam kualitas berita adalah sifat objektif suatu berita. Standar untuk menilai imparsialitas media dilihat pada keseimbangan dalam memilih narasumber yang menyampaikan berbagai pandangan dan tidak ada keberpihakan serta menghindari penggunaan kata-kata atau gambar emosional yang dapat menggiring penilaian atau penafsiran penonton.

Perangkat framing Robert N. Entman yang melihat pembingkaian dalam dua dimensi besar yakni seleksi isu dan penonjolan aspek-aspek tertentu dari realitas atau suatu isu. Dalam aspek seleksi isu berkaitan dengan pemilihan fakta, aspek mana yang dipilih untuk ditampilkan dan dalam proses ini selalu ada bagian berita yang dimasukan maupun diabaikan tidak semua aspek dari suatu isu ditampilkan, sedangkan penonjolan aspek tertentu dari suatu isu berkaitan dengan penulisan fakta dengan pemilihan kata, kalimat, maupun citra yang ditampilkan kepada khalayak (Eriyanto, 2002). Framing digunakan untuk mengetahui perspektif atau sudut pandang yang digunakan oleh media dalam membuat berita.

Melalui penelitian ini peneliti melihat bahwa Republika lebih aktif dan lebih banyak memuat pemberitaan tentang film 212: The Power of Love dibanding berita tentang film $A$ Man Called Ahok, sedangkan CNN Indonesia lebih banyak memuat pemberitaan tentang film A Man Called Ahok, hal ini dapat diketahui dari perbandingan jumlah berita terkait film $A$ Man Called Ahok dan film 212: The Power of Love yang dimuat pada Gambar 3.

Republika memuat berita tentang film 212: The Power of Love sebanyak 22 berita dan memuat film A Man Called Ahok sebanyak 8

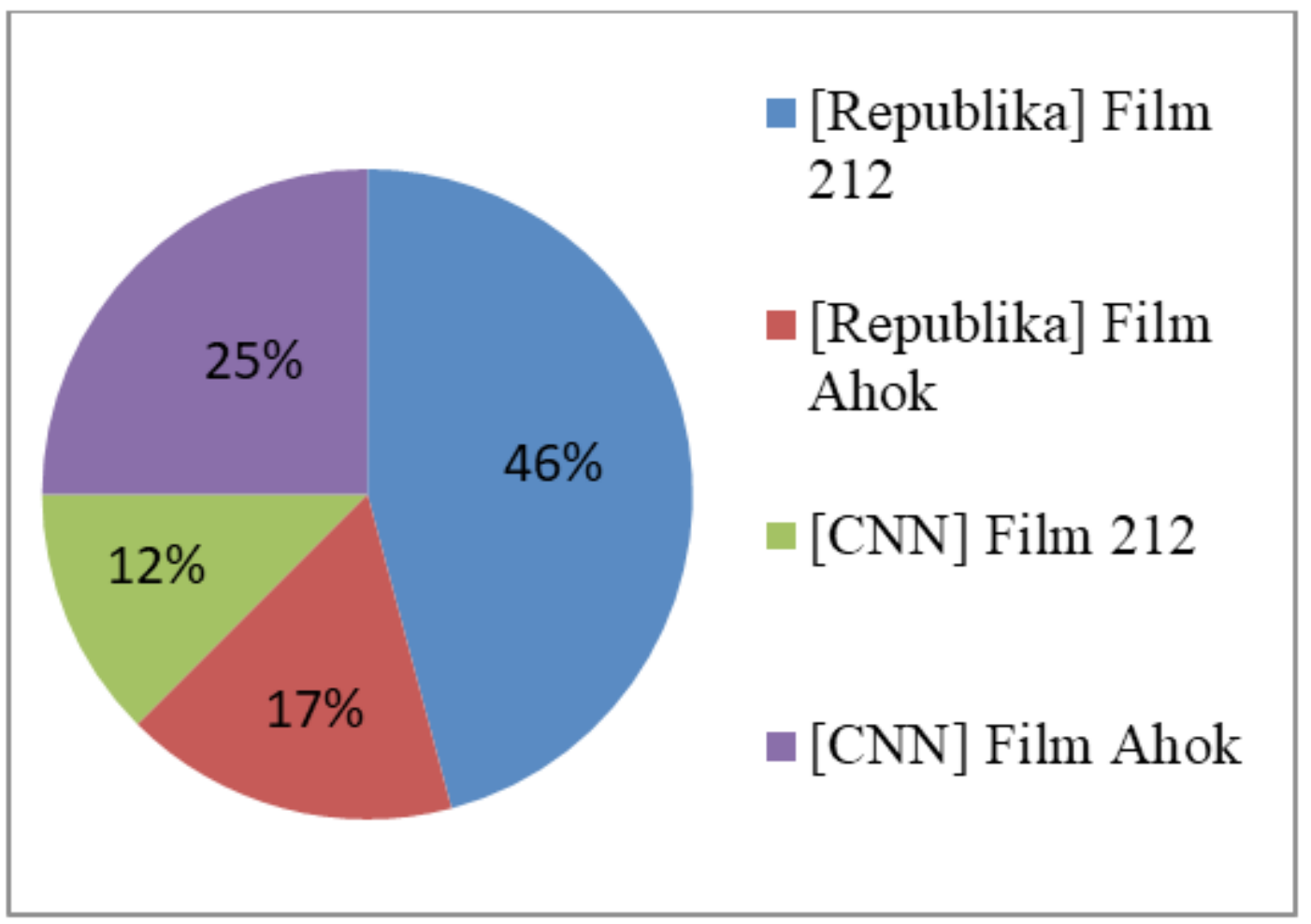

Sumber: Hasil penelitian, 2019

Gambar 3 Perbandingan Jumlah Berita 
berita. CNN Indonesia memuat berita tentang film 212: The Power of Love sebanyak 6 berita dan film A Man Called Ahok sebanyak 12 berita. Berdasarkan banyaknya berita yang dimuat dapat dilihat apa yang dianggap penting oleh Republika dan CNN Indonesia berbeda karena semakin dianggap penting isu tersebut maka media akan semakin sering meyampaikannya. CNN Indonesia tidak hanya sekedar membuat pemberitaan tetapi juga menyajikan ulasan dan analisis terkait kedua film tersebut. Dari sepuluh berita yang dijadikan sampel penelitian, media Republika maupun CNN Indonesia sama-sama memandang kedua film tersebut dengan positif tetapi Republika cenderung lebih menonjol dalam pemberitaan film 212: The Power of Love berdasarkan banyaknya jumlah berita untuk film 212 bahkan berita yang terbit sekaligus dihari yang sama dan ada beberapa berita yang isinya serupa dengan nada positif atau pujian pada film 212 menunjukan antusiasme yang tinggi dari Republika untuk film 212: The Power of Love. Berbeda dengan CNN Indonesia yang lebih tenang atau secukupnya dalam memuat berita dan objektif dalam menilai karena baik penilaian secara positif maupun negatif turut dimuat dalam isi beritanya membuat isi berita menjadi seimbang.

Dari segi narasumber, peneliti menemukan bahwa narasumber yang ditampilkan oleh Republika semuanya berasal dari pihak masingmasing film dan hanya Ketua Majelis Ulama Indonesia (MUI) Bidang Seni dan Budaya Islam yang berasal dari luar film tetapi masih mengatas namakan agama Islam, hal tersebut bisa membuat pemberitaan jadi semakin subjektif karena pihak film tentu akan mendukung dan membawa nilai baik untuk filmnya sendiri dan KH Sodikun dari pihak MUI dianggap menjadi penguat dukungan untuk film 212: The Power of Love sebagai film Islami. Sedangkan CNN Indonesia dalam pemberitaannya yang juga memuat analisis menampilkan narasumber dari berbagai pihak seperti Joko Anwar seorang sutradara film, Dadang Rahmat Hidayat pengamat komunikasi politik, dan Ubedilah Badrun pengamat sosiologi politik, CNN Indonesia juga menampilkan banyak data seperti jumlah layar dan penonton dari bioskop- bioskop diberbagai kota, hal tersebut membuat informasi yang disampaikan menjadi lebih kaya, objektif, dan bisa menjadi bahan edukasi bagi khalayak.

Republika selalu menonjolkan sisi positif dari film 212: The Power of Love dari mulai judul berita "Film 212: The Power of Love Diapresiasi", "Film 212 jadi Penyejuk di tengah Teror Bom Surabaya", bahkan di judul "Erick Yusuf Terima Keluhan Sulitnya Tiket Film 212" yang bernada kekecewaan itu sebagian beritanya tetap berisikan dukungan dan pujian pada film 212, Republika seperti tidak bisa melepaskan dukungan penuh dan pujiannya terhadap film 212 yang membawa nilai Islami dalam semua pemberitaannya terkait film tersebut, tetapi Republika terlihat sangat santai dalam memberitakan film A Man Called Ahok dan hanya mengulik sedikit latar belakang film Ahok. CNN Indonesia dalam pemberitaannya terlihat cenderung netral, walaupun memang lebih banyak menyajikan pemberitaan film Ahok tetapi CNN Indonesia tidak berlebihan dalam menyatakan dukungan untuk film tersebut, dan dalam menyajikan pemberitaan film 212: The Power of Love CNN Indonesia turut menilai film itu baik dari segi moral tetapi kualitas filmnya dianggap kurang baik, CNN Indonesia juga menilai euforia masa promosi film 212 terlalu berlebihan.

Republika tidak banyak menampilkan penyelesaian masalah dalam pemberitaannya, karena pemberitaannya pun tergolong hanya sekedar memberi informasi tanpa adanya masalah penting yang ingin ditunjukan. CNN Indonesia menampilkan penyelesaian masalah yang sederhana dibeberapa pemberitaan terutama pemberitaan yang terkait analisis berjudul "Polarisasi Bangsa di Balik film Ahok dan Hanum".

Aspek yang jelas ditonjolkan oleh Republika adalah dalam pemberitaan tentang film 212 selalu ada kalimat pujian yang ditampilkan untuk film 212 dan diperkuat pula oleh pernyataan dari para narasumber pilihan Republika yang mendukung film 212, yang juga ditonjolkan oleh Republika adalah film 212 yang dinilai humanis, mencerminkan Islam yang baik, serta universal. Sedangkan untuk 
pemberitaan tentang film Ahok, Republika hanya menonjolkan satu hal yakni film tersebut tidak menyinggung soal politik. Dalam CNN Indonesia tidak banyak hal yang ditonjolkan karena pemberitaanya cenderung netral, $\mathrm{CNN}$ Indonesia hanya membingkai film 212 sebagai film yang positif dalam nilai moral terutama agama Islam namun segi kualitas film 212 memiliki banyak kekurangan, dan juga ambisi dari film 212 yang kuat namun kenyataannya sulit mencapai ekspektasi untuk 'memutihkan bioskop' atau mendapat 1 juta penonton. Untuk film A Man Called Ahok CNN Indonesia membingkainya sebagai film yang apik dari segi cerita maupun kualitas filmnya, film ini juga banyak ditunggu oleh masyarakat lantaran sosok Ahok yang terkenal, dan isu politik yang melingkupi film Ahok dianggap terjadi karena kurangnya edukasi politik gagasan dimasyarakat dan menjadi penguat polarisasi politik yang sebenarnya sudah lama terjadi.

Aspek yang tidak ditampilkan oleh Republika dalam pemberitaannya adalah pendapat dari narasumber diluar alumni aksi 212 dan diluar pihak film 212 maupun film Ahok. Sebaiknya Republika turut menampilkan ulasan dari para sineas tanah air atau kritikus film untuk memberikan pendapat tentang film 212 yang ditonjolkan oleh Republika agar pemberitaannya lebih berwarna. Republika tidak menampilkan alasan lain mengapa film 212 mendapat jumlah penonton yang sedikit selain karena keterbatasan layar bioskop. CNN Indonesia juga tidak menambahkan narasumber dalam pemberitaan ulasan film 212 dan film Ahok, ulasan itu terlihat hanya opini dari si pembuat berita saja.

Bagian 6: Konstruski Sosial Media Massa. Sebuah berita yang harusnya bersifat objektif akan menjadi bahan pertimbangan karena semua berita yang dihasilkan oleh media merupakan hasil dari konstruksi media massa itu sendiri. Hal ini sejalan dengan pandangan konstruktivisme. Istilah konstruktivisme oleh Littlejohn, digunakan untuk menjelaskan teori yang menyatakan bahwa setiap individu menafsirkan sesuatu dan berperilaku sebagaimana konsep pemikirannya. Realitas muncul setelah disaring dengan cara pandang seseorang yang berbeda-beda tentang setiap hal yang ada. Pandangan konstruktivisme meyakini bahwa media merupakan agen yang mengkonstruksi realitas.

Bagaimana sebuah realitas dibentuk dalam suatu berita tergantung pada bagaimana realitas tersebut dipahami oleh wartawan atau media yang dalam prosesnya melibatkan ideologi dan pandangannya masing-masing. Hal ini sesuai dengan pemikiran dari teori konstruksi sosial media massa yang juga melihat begitu besar dan cepatnya pengaruh media.

Pergerakan informasi yang sangat cepat dan luas dan menyebabkan konstruksi sosial yang turut berlangsung cepat merupakan substansi dari teori "konstruksi sosial media massa", realitas yang dikonstruksi juga membentuk opini massa. Terbentuknya proses simultan tersebut melalui tahapan-tahapan penting, sebagai berikut: (a) tahap menyiapkan materi konstruksi; (b) tahap sebaran konstruksi; (c) tahap pembentukan konstruksi; dan (d) tahap konfirmasi (Tamburaka, 2012).

Berita yang disajikan oleh Republika dan CNN Indonesia dihasilkan dari pemaknaan para wartawan yang pada dasarnya setiap orang pasti memiliki pemaknaan yang berbeda atas suatu realitas dan akhirnya menciptakan realitas yang berbeda pula, maka berita yang disajikan oleh Republika dan CNN Indonesia ialah hasil konstruksi kerja para jurnalisnya dan bisa dianggap pantas jika pemberitaannya bersifat subjektif.

Dalam mengkonstruksi pemberitaan tentang film A Man Called Ahok dan film 212: The Power of Love Republika dan CNN Indonesia melalui tahapan-tahapan konstruksi seperti yang diungkapkan oleh Bungin dimana tahapan pertama adalah Tahap menyiapkan materi konstruksi dimulai dari pemilihan isu yang diangkat (Bungin, 2008) oleh Republika dan CNN Indonesia. Dalam pembahasan ini isu yang diangkat terkait pemberitaan film $A$ Man Called Ahok dan film 212: The Power of Love. Dalam mengangkat isu ini Republika lebih banyak memberitakan film 212: The Power of Love sedangkan CNN Indonesia lebih banyak memberitakan film A Man Called Ahok, yang bisa ditangkap dalam hal ini adalah bahwa 
semakin sering sebuah isu itu dimunculkan oleh media maka isu tersebut dianggap penting oleh media tersebut dan apa yang dianggap penting oleh media maka akan dianggap penting juga oleh khalayaknya. Informasi yang ditampilkan oleh media juga memiliki sifat yang berbeda bisa dipengaruhi oleh keberpihakan media tersebut serta sudut pandang yang ingin dibangun oleh media tersebut.

Dari sampel penilitian yang telah dianalisis terlihat CNN Indonesia yang cenderung netral tetap menunjukan keberpihakannya pada film A Man Called Ahok dan jelas bahwa Republika sangat memihak film 212: The Power of Love dilihat dari dukungan dan promosi yang menonjol, pengulangan kalimat pujian untuk film 212 dalam tiga judul berita yang peneliti analisis.

"Film ini perlu hadir untuk mengabadikan momen 212. Dan membuktikan Islam itu rahmatan lil alamin. Rumput tak ada yang diinjak. Sampah kelar aksi, semua dipungut dan dibersihkan. Bahkan masyarakat kecil ikut menggratiskan cemilan yang menjadi nafkah mereka sehari-hari," kata Oki Setiana Dewi. Salah satu pemeran film 212 The Power of Love, Echy Yiecxel (nonMuslim) berkata, «Ini bukan film untuk umat Islam saja tapi untuk semua kalangan. Sangat humanis dan mengandung banyak nilai kemanusiaan yang universal." Helvy Tiasa Rosa tidak hanya memproduseri film 212 The Power of Love. Ia juga menulis novel yang diadaptasi dari film tersebut dengan judul 212 Cinta Menggerakkan Segala. Novel tersebut diterbitkan oleh Republika Penerbit. Film 212 The Power of Love tayang di bioskop nasional mulai Rabu (9/5). Baik Asma Nadia maupun Helvy Tiana Rosa mengajak masyarakat seluas-luasnya untuk menonton film tersebut di bioskop sejak hari pertama penayangan.'Yuk, ramai-ramai kita putihkan bioskop mulai tanggal 9 Mei 2018. KIta dukung film 212 maupun filmfilm Islam lainnya yang bermutu baik dan bermanfaat bagi masyarakat," kata Asma Nadia."Ayo ramai-ramai kita dukung film 212 dengan cara menonton di bioskop sejak hari pertama penayangan. Inilah cara kita agar film 212 bisa bertahan di bioskop, bahkan mendapatkan tambahan layar," ujar
Helvy Tiana Rosa. (Judul berita: Film 212 The Power of Love Diapresiasi, paragraf 10-15).

Di sisi lain, ia mengatakan, pujian terus mengalir dari penonton film yang menceritakan aksi damai 7 juta umat Islam pada 2 Desember 2016 di Monas, Jakarta Pusat, tersebut. "Alhamdulillah kalau pujian mengalir terus," ujar dia. Ia mencontohkan, banyak penonton yang terkejut setelah menonton film 212: The Power of Love. Banyak komentar yang diterima Erick, film tersebut menceritakan dan memperlihatkan cinta secara keseluruhan, baik pada negara, agama, keluarga, orang tua, maupun sesama."Kita betul-betul bicara tentang kisah Islam, rasa kasih sayang dan cinta. Kita dorong seperti itu bahwa Islam yang sebenarnya yang seperti itu, bukan yang marah-marah," tutur Erick. (Judul berita: Erick Yusuf Terima Keluhan Sulitnya Tiket Film 212, paragraf 4-6).

Film ini, menurut Sodikun, bukan hanya pantas ditonton oleh umat Muslim, melainkan seluruh lapisan masyarakat. Film ini dinilainya tidak hanya bercerita soal agama, tetapi juga mengandung pesan tentang toleransi serta kisah yang luas tentang rasa cinta pada keluarga dan lingkungan."Saya melihat film ini tidak hanya perlu ditonton untuk saudara kita segama, katakanlah agama Islam, tetapi ditonton juga untuk seluruh anak bangsa," kata Sodikun. Menurut Sodikun, pesan yang terkandung dalam film ini bukan hanya untuk umat Islam, melainkan sangat universal. Banyak pesan tentang cinta dan kedamaian. Selain itu, budaya Indonesia yang familiar banyak terlihat di film ini. (Judul berita: Film 212 Jadi Penyejuk di Tengah Teror Bom Surabaya, paragraf 3-5).

Republika menyajikan informasi sama yang berulang dengan hanya mengganti judul berita dan mencantumkan narasumber yang berbeda tetapi isi komentar yang serupa, penyajian informasi film 212 yang berulang-ulang ini semakin menguatkan bahwa film 212 dianggap penting oleh Republika, Republika juga menonjolkan nilai Islami dipemberitaannya. 
Hal ini bisa terjadi karena segmentasi Republika pada umat Muslim dan sudah masuk dalam Tahap sebaran konstruksi. CNN Indonesia memiliki segmentasi khalayak lebih umum maka tidak terlihat penonjolannya pada aspek tertentu dari kelima berita yang dianalisis.

Tahap pembentukan konstruksi realitas menampilkan citra yang dibangun oleh tahap konstruksi, dimana konstruksi citra yang dibangun oleh media massa terbagi dalam dua model yakni bad news (berita buruk) dan good news (berita baik). Di tahapan ini Republika selalu menampilkan citra good news dalam pemberitaannya baik tentang film A Man Called Ahokmaupun film 212: The Power of Love, tetapi CNN Indonesia memberikan citra yang tidak terlalu bagus untuk film 212: The Power of Love dalam pemberitaannya lebih mengarah pada bad news, dan memberi citra yang bagus untuk film A Man Called Ahok. Di Tahap konfirmasi peneliti menilai bahwa Republika menampilkan citra good news dan mengkonstruksi banyak nilai Islami serta menampilkan dukungan menonjol untuk film 212 yang bernafaskan Islami dikarenakan segmentasi khalayaknya serta visi misi dari Republika yang merupakan media umat Muslim. Dan CNN Indonesia menampilkan citra bad news untuk film 212: The Power of Love merupakan hasil konstruksi atau pemaknaan dari jurnalis CNN Indonesia sendiri, begitupun dengan film A Man Called Ahok yang dikonstruksi sebagai film yang bagus oleh CNN Indonesia.

Informasi yang diciptakan media berubah dengan sangat cepat dan khalayak menjadi sadar adanya perbedaan dalam kebenaran, hal ini membuat orang bingung dan tidak tenang. Maka dari itu, sebagai khalayak dari media massa, masyarakat juga dituntut untuk menjadi khalayak yang aktif agar dapat mengkritisi terpaan media, sehingga muatan media massa dapat diarahkan untuk kemaslahatan umat manusia sesuai dengan fungsi sosial yang ada dalam media massa (Abdullah, 2018).

\section{SIMPULAN}

Setelah menganalisis keseluruhan isi berita Republika dan CNN Indonesia serta membandingkannya dengan teori yang ada, peneliti menarik kesimpulan sebagai berikut:

Pendefinisian masalah (define problems) oleh Republika online tentang film 212: The Power Of Love dibingkai sebagai film Islam yang sangat bagus dan bermanfaat, film 212 dianggap menjadi pencerahan dan penyejuk bagi masyarakat yang berpandangan negatif terhadap film dan aksi 212 maupun pandangan negatif terhadap Islam, di sini Republika terlihat sangat mendukung film 212 terlihat dari kalimat pujian untuk film 212 yang selalu muncul dalam pemberitaannya. Republika online dan $\mathrm{CNN}$ Indonesia mendefinisikan film A Man Called Ahok sebagai film biografi yang menceritakan kisah hidup Ahok tanpa menyinggung dunia politiknya. CNN Indonesia mendefinisikan masalah film 212: The Power Of Love memiliki euforia berlebihan serta kegagalan mencapai ambisinya untuk 'memutihkan bioskop' .

Penyebab masalah (diagnose causes) menurut Republika masalah keterbatasan layar untuk film 212 yang diberikan oleh pihak bioskop yang menyebabkan banyak masyarakat yang sulit mendapat tiket film 212. Menurut CNN Indonesia penyebab masalah film 212 tidak hanya dari pihak bioskop tetapi juga kualitas filmnya yang memiliki banyak kekurangan baik dari segi cerita maupun segi teknis. Untuk film A Man Called Ahok Republika dan CNN Indonesia sama-sama membingkai dugaan politik di masyarakat kepada film A Man Called Ahok, yang menyebabkan beragam kontroversi muncul, serta kurangnya edukasi politik gagasan di masyarakat pendukung kubu politik ditambah era demokrasi digital yang banyak memanfaatkan kanal-kanal media termasuk media film.

Keputusan moral (make moral judgement) yang ditunjukan oleh Republika online dan CNN Indonesia adalah dukungan terhadap film 212 yang mencerminkan nilai-nilai Islami, kemanusiaan, rasa cinta dan kekeluargaan dan film A Man Called Ahok yang menunjukan pesan moral melalui makna filmnya yang sangat inspiratif mengisahkan hubungan antara orangtua terutama hubungan ayah dan anak.

$\begin{array}{rcr}\text { Penyelesaian } & \text { masalah (treatment } \\ \text { Republika online tidak }\end{array}$ 
banyak memberikan solusi dalam setiap pemberitaannya, selain hanya meminta masyarakat agar tidak berburuk sangka atau menilai sebelum menonton film 212. CNN Indonesia menyarankan untuk menambah jumlah kopi-an film dan pengerahan massa alumni aksi 212 melalui media sosial untuk menambah jumlah penonton dan mendorong bertambahnya jumlah layar yang diberikan pihak bioskop, dan solusi untuk masalah isu politik film A Man Called Ahok CNN Indonesia menampilkan saran untuk para elit politik agar memberikan edukasi politik gagasan kepada para pendukungnya agar tidak terjadi lagi fenomena serupa yang mengaitkan film dengan kepentingan politik.

Media Republika online sebaiknya lebih banyak menyajikan data yang relevan dalam pemberitaannya, agar suatu isu yang diangkat menjadi lebih berbobot dan semakin kuat alasan mengapa isu tersebut layak disajikan pada khalayak. Karena berita media harus proporsional, didasarkan pada topik yang sesuai untuk masyarakat serta menggambarkan bervariasinya minat dan kebutuhan audien pada berita. Hal ini peneliti tekankan karena peneliti menilai Republika dalam menyajikan berita tentang film 212: The Power Of Love terlalu menonjol bahkan berlebihan muatan beritanya menjadi seperti sebuah iklan. Dan untuk CNN Indonesia sebaiknya turut menyajikan narasumber lain seperti dari sudut pandang penonton masyarakat umum, agar ulasannya bisa menampilkan sudut pandang dari berbagai pihak.

Untuk kedua media serta media lainnya peneliti berharap agar kedepannya bisa membuat pemberitaan yang lebih objektif, terutama dalam pemberitaan film karena dengan membaca pemberitaan dari media massa tentang suatu film apalagi jika berita tersebut disajikan berulang-ulang hal tersebut akan sangat memengaruhi keputusan khalayak untuk menonton film tersebut atau tidak, dan pilihan khalayak untuk menonton film itu bukan lagi menikmatinya sebagai sebuah karya seni tetapi khalayak menonton film tersebut karena hasil konstruksi media massa.

Penelitian selanjutnya diharapkan dapat menganalisis film A Man Called Ahok maupun film 212 The Power Of Love menggunakan analisis semiotika untuk melihat dan membuktikan apakah ada simbol-simbol politik dalam film tersebut.

\section{DAFTAR PUSTAKA}

Abdullah, A., Rosfiantika, E., \& Puspitasari, L. (2018). Sosialisasi profesi wartawan bagi para kepala sekolah dasar se-kecamatan Lembang Kab. Bandung Barat. Jurnal Pengabdian Kepada Masyarakat Vol. 2, No. 10. http://jurnal. unpad.ac.id/pkm/article/view/20358/9887.

Agustina, L. (2017). Framing aksi damai 2 Desember 2016 di media online. https://www. researchgate.net/profile/Lidya_Agustina4.

Alauddin, A. (2018). Konstruksi pemberitaan kasus Ahok di media online tentang penistaan agama. http://digilib.uinsby.ac.id/22866.

Alexa. (2018). Top sites in Indonesia. Diakses dari https://www.alexa.com/topsites/countries/ID.

Ardianto, E., Lukiati, K., \& Siti, K,. (2007). Komunikasi massa suatu pengantar. Bandung. Penerbit: Simbiosa Rekatama Media.

Bungin, B. (2008). Konstruksi sosial media massa: kekuatan pengaruh media massa, iklan televisi, dan keputusan konsumen serta kritik terhadap Peter L. Berger \& Thomas Luckmann. Jakarta. Penerbit: Prenada Media Group.

CNNIndonesia. (2018). Polarisasi bangsa di balik film Ahok dan Hanum. Diakses dari:https://www.cnnindonesia.com/ nasional/20181114021615-20-346329/ polarisasi-bangsa-di-balik-film-ahok-danhanum pada Maret sampai 10 Juli 2019.

Eriyanto. (2002). Analisis framing: konstruksi, ideologi, dan politik media. Yogyakarta. Penerbit: LKiS Printing Cemerlang.

Film Indonesia. (2018). Data penonton tahun 2018. Diakses dari http://filmindonesia.or.id/movie/ viewer/2018\#.XITbBMAzbIU.

Karman. (2012). Media dan konstruksi realitas. Jurnal Studi Komunikasi dan Media, Vol. 16, No. 1. https://jurnal.kominfo.go.id/index.php/ jskm/article/download/160102/9.

Kelana, I. (2018). Film 212 the power of love diapresiasi. Diakses dari https://senggang. republika.co.id/berita/p8iz1s374/film-em212the-power-of-loveem-diapresiasi.

McQuail, D. (2011). Teori komunikasi Massa McQuail. Jakarta. Penerbit: Salemba Humanika.

Morissan. (2010). Teori komunikasi massa: media, budaya, dan masyarakat. Bogor: Ghalia. 
Mulyana, D. (2008). Ilmu komunikasi suatu pengantar. Bandung: Remaja Rosdakarya.

Nugroho, C. (2018). Relasi kuasa media dan isu gender dalam program televisi di Indonesia. ProTVF, Vol. 2, No. 2. https://doi.org/10.24198/ ptvf.v2i2.20816.

Pawito. (2009). Komunikasi politik: media massa dan kampanye pemilihan. Yogyakarta: Jalasutra.

Permana, R. S. M., Abdullah, A. \& Mahameru, J. N. (2019). Budaya menonton televisi di Indonesia: dari terestrial hingga digital. ProTVF, Vol. 3, No. 1. http://jurnal.unpad.ac.id/protvf/article/ view/21220/10504.

Priherdityo, E. (2018). Mengukur kemampuan film '212' memutihkan bioskop. Diakses dari https://www.cnnindonesia.com/ hiburan/20180509224055-220-297080/ mengukur-kemampuan-film-212memutihkan-bioskop.

Putra, M. A. (2018). Ulasan film: 212 the power of love. Diakses dari https://www.cnnindonesia. com/hiburan/20180510104430-220-297133/ ulasan-film-212-the-power-of-love.

Republika. (2018). Film 212 the power of love. Diakses dari https://republika.co.id/search/ film $\% 20212 \% 20$ power $\% 20$ of $\% 20$ love.

Rezkisari, I. (2018). Film 212 jadi penyejuk di tengah teror bom Surabaya. Diakses dari: https:// senggang.republika.co.id/berita/p8sufl328/ film-em212em-jadi-penyejuk-di-tengah-terorbom-surabaya.

Tamburaka, A. (2012). Agenda setting media massa. Jakarta: Rajawali Pers.

Wazis, K. (2012). Media massa dan konstruksi realitas. Malang: Aditya Media Publishing. 